DOI: $10.21608 / z v j z .2017 .29247$.

\title{
Pharmacological Studies on Bleomycin as Cancer Therapy and Protective Effect of Aged Garlic
}

\author{
Sabry M.A. Abdel-Motal ${ }^{1}$, Mohamed H. Khairy ${ }^{1}$, Ahmed A. S. Mohamed ${ }^{1}$, Magdy F. Abou El- \\ Fotoh $^{2 *}$ and Shimaa A. Abdel -Aziz ${ }^{1}$ \\ ${ }^{1}$ Pharmacology Department, Faculty of Veterinary Medicine, Zagazig University, Zagazig, \\ Egypt \\ ${ }^{2}$ Forensic Medicine and Toxicology Department, Faculty of Veterinary Medicine, Zagazig \\ University, Egypt
}

\begin{abstract}
The pharmacological impacts of bleomycin as anticarcinogenic agents and the protective effect of aged garlic were done in current study. Eighty mature male albino mice were divided into 8 groups (each ten mice), group one was kept as a negative control, group two which was injected intraperoteneally with bleomycin. Group 3, which was given orally aged garlic, group 4 was inoculated with Ehrlich Ascites Carcinoma cells (EAC), animals of group 5were administrated aged garlic and injected with EAC cells while group 6 was given simultaneously EAC cells and bleomycin I/P , group 7 was injected bleomycin I/P and administrated garlic 8 days later and group 8 took both bleomycin and garlic before inoculation of EAC cells by 8 days. Our results revealed that there were side effects of bleomycin on GSH, ROS, CAT, GPX and GR in the inoculated groups with EAC cells and confirmed by biochemical analysis. Aged garlic suppresses the progression of EAC cells and prevents their developmental effects.
\end{abstract}

Keywords: Bleomycin, Cancer Therapy, Protective Effect, Aged Garlic

\section{Introduction}

Cancer is a major public health threatening disease in. developed countries and it's still one of the most serious causes of death in the world with no major progress in reducing its morbidity and mortality [1]. Chemotherapeutie agents are medications that destroy dividing cancer cells by targeting different phases in the cancer cell's life cycle. Since various agents attack the cancer cell differently, they are commonly given in combination for maximum beneficial effect. Once you understand that chemotherapy is designed to kill rapidly dividing cancer cells, you realize that it can also attack other rapidly dividing cells within the body. As hair skin, nails, gastrointestinal tract and bone marrow will be under assault. This hit on healthy cells is which is leads to the most common side effects of chemotherapy [2].

The use of chemical agents to destroy cancer cells is a main stay in the treatment of malignancies. The possible role in treating illness y/as discovered when bone marrow suppressive effect of nitrogen mustard was noted in the early 1900 's. Since that time, the search for drugs with anticancer activity has continued, and the goal of treatment with chemotherapy has evolved from relief of symptoms for cancer cure, A major advantage of chemotherapy is its ability to treat wide spread or metastatic cancer, whereas surgery and radiation therapy are limited to treat cancer, confined to specific areas [3].

Cancer chemotherapy can he divided into several categories; Alkylating agents (eg: cyclophosphamide, ifosfamide). Antibiotics which affect nucleic acids (eg: doxorubicin, bleomycin), platinum compounds (eg: cisplatin), Mitotic inhibitors (eg: vincristine), antimetabolites (eg: 5-Flurouracil), Compotothecin drevatives (eg: Topotecan), biological response modifiers (eg: Interferon) and hormone therapies (eg: Tamoxafen). The alkylating agents and the antitumor antibiotics are the most creating cellular damage by initiating free radical oxidants [4]. Antitumor Antibiotich includes: Bleomycin, Dactinomycin, Daunorubicin, Doxorubicin, Idarubicin, Mitomycin, Mitoxantrone, Plicamycin [5].

Bleomycin (BLM) is an antitumor antibiotic which is a mixture of a purified glycopeptides produced by a fermentation process isolated originally from fungus 
streptomyces - Verticilfiis discovered by Umezawa et al. [6]. It is commonly used as part of the cytotoxic treatment of several tumors such as germ cell tumors, Lymphomas including Hodgkin's disease, non-Hodgkin's lymphoma, kaposi's sarcoma sna squamous cell carcinomas of head and neck including: mouth, tongue, tonsil, nasopharynz., oropharynx, sinus, palate, lip, buccal mucosa, goingivae, epiglottis, skin, larynx, penis, cervix, and vulva. The response to BLM is poorer in patients with previously irradiated head and neck cancer. This medication may also be used to control the buildup of the fluid around the lungs (pleural effusion) caused by tumors that have spread in the lungs. For this condition bleomycin is placed in the space around the lungs through a chest lube [7].

BLM is also one component of the ABCD system (doxorubicin, (adriamycin). blemoyein, vinblastine and darcarbacin) that is a standard schedule treatment for advanced Hodgkin's lymphoma. This system has little toxicity compared to others as MOPP and minimal potential for inducing second neoplasias or patient sterility also it is used to treat early disease stages [8]. BLM is widely used in experimental models to cause lung injury leading to oxidant-induced inflammatory and fibrotic lesions in the lung interstitium of various animal species [9]. This animal model of pulmonary fibrosis resembles that seen in humans and it is useful to assess the effects of potential therapeutic agents including antioxidants [10].

BLM exerts its antitumor effect by inducing tumor cell death by induction of free radicals causing DNA breaks [11]. It can be given by several routs; IV, IM, or SC. In case of malignant effusion' it can be administered IP or intra pleural [12]. BLM is known to produce pulmonary fibrosis in humans as well as in experimental animals. Application of BLM is fentured by the occurrence of sometimes fatal side effects. Due to the lack of the BLM- inactivating enzyme, BLM hydrolase, in the lungs and the skin, bleomycin-induced toxicity occurs predominantly in these organs directly after its administration, the occurrence of fever, chills, and sometimes hypotension is well known [13] .
The most frequent event is pneumonitis occasionally progressing to pulmonary fibrosis. Approximately $10 \%$ of patients treated with BI.M have died by pulmonary fibrosis. The most common changes in pulmonary function tests are decrease in total lung volume and decrease in vital capacity. The process of fibrosis is important in the lung since its progression may results in respiratory failure and poor prognosis in patients with a heterogenous group of disorders of known and unknown etiology. The progression of fibrosis is closely controlled by complicated network consisted of many cytokines, chemical mediators, growth factors and biophysical peptides derived from inflammatory immune cells and alveolar type II cells. These cells which accumulate in the lower air ways release a harmful amount of (ROS) [14].

Recently it has been suggested that reactive nitrogen species (RNS) including nitric oxide (NO), peroxynitrile $\left(\mathrm{ONOO}^{-}\right)$and nitrogen dioxide which are released from neutrophile and macrophages play an important role in the pathogensis of lung disease [15]. The cytotoxic activity of BLM depends on generation of single- and double-strand breaks in DNA [16]. Indispensable for this BI.M activity is the presence of metal ions, specifically $\mathrm{Fe}^{2+}, \mathrm{Fe}^{3+}$ BLM with $\mathrm{O}_{2}$ or $\mathrm{Fe}^{3+}$ BLM complexed with $\mathrm{H}_{2} \mathrm{O}_{2}$ leads to formation of an active $\mathrm{BLM}$ molecule, $\mathrm{HOO}^{-} \mathrm{Fe}^{2+} \mathrm{BLM}$. BLM specifically induces DNA double strand breaks and apurinic / apyrimidinic sites in the complementary strands with a higher frequency than would result from randomly induced damage. It is expected that double strand break is generated by a BM molecule which is reactivated after nicking the first strand. The reactivation consists of reduction of BLM Fe${ }^{3+}$ (formed after reaction with DKA) to BLM Fe $\mathrm{Fe}^{2+}$ and a subsequent addition of an oxygen molecule leading to the generation of the active from of BLM [17].

BLM induces both chromatid and chromosome type aberrations (deletions, diand multicentrics, rings, exchanges, breaks), but does not induce sister chromatid exchanges. Accordingly, interphase cells after BLM treatment show the presence of micronuclei [18]. The viability test for detection the viability of Ehrlich Ascites 
carcinoma cells (EAC) in mature male albino mice was done in this study. Using bleomycin as anti-tumorigenic and detecting its side effects. Besides determination of sperm abnormalities in male mature mice and determination of antioxidants enzymes as glutathione reductase, reduced glutathione, glutathione - S-tranferase, superoxide dismutase and catalase enzymes were also studied .

\section{Material and Methods}

\section{Experimental animals}

Eighty adult male Swiss albino mice weighted $30-50 \mathrm{gm}$ were obtained from the Laboratory Animal Housing Unit, Animal Health, Research Institute, Dokki, Cairo, Egypt. The animals were clinically healthy, kept under hygienic conditions. Housed in metal cages with hard wood shavings as bedding. They were maintained on balanced ration, water and the food were giving adlibtum throughout the experimental period. The animals were accommodated to the laboratory conditions for one week before beginning of experiment.

\section{Tumor Cell Line}

\section{Ehrlich Ascites Carcinoma cells (EAC)}

The parent line of Ehrlich Ascites Carcinoma cells was initially supplied by the National Cancer Institute, Cairo University, Egypt, and maintained in mature male Swiss albino mice through serial intraperitoneal inoculation of [EAC] $2.5 \times 10^{6}$ tumor cells/0.2 $\mathrm{ml}$ at 7-8 day intervals in the laboratory in an ascites form was detected.

\section{Transplantation of Tumor in mice}

EAC cells were collected from moderately growing 7 days old donor. After making appropriating dilution, the viability was checked by the trypan blue exclusion test 0.2 $\mathrm{ml}$ portions of ascetic fluid containing $2.5 \mathrm{x}$ $10^{6}$ viable cells were intraperitoneally injected in a group of healthy mice for maintenance of the line and for experimental work.

\section{Bleomycin (BLM)}

BLM was obtained in commercial form (Bleocin). The drug was obtained from Salides Pharma. The drug was produced by Nippon kayaku.Co. Ltd (Tokyo-Japan). Each vial contain Bleomycin Hydrochloride $15 \mathrm{mg}$ potency.

\section{Aged garlic extract (AGE)}

Preparation n of AGE was carried out [19]. The Egyptian garlic gloves (Alium satirum) were sliced and soaked in $20 \%$ ethanol $(80 \%$ water and $20 \%$ ethanol mixture) in dark coloured glass bottles (200 gm/liter). The garlic was aged naturally for 20 months at room temperature. The alcohol was found to have no effect except to inhibit bacterial and fungi growth. The extract was then filtered and tested bacteriologically and fungi on nutrient agar and S.S. media respectively.

Table 1 Experimental design and grouping

\begin{tabular}{|c|c|c|c|}
\hline Treatment & $\begin{array}{l}\text { Aged garlic } 2 \text { gm/kg } \\
\text { b.wt. stomach lavage }\end{array}$ & $\begin{array}{l}\text { bleomycin } 15 \mathrm{gm} / \mathrm{kg} \\
\text { b.wt. I/P }\end{array}$ & $\begin{array}{l}\text { Ehrlich Ascites } \\
\text { carcinoma (EAC) I/P }\end{array}$ \\
\hline Negative control & -ve & -ve & -ve \\
\hline Positive control & -ve & + ve & -ve \\
\hline Positive Control & $+\mathrm{ve}$ & -ve & -ve \\
\hline (inoculated) control & -ve & -ve & + ve \\
\hline $\begin{array}{l}\text { Aged garlic and inoculated with EAC } \\
\text { cells }\end{array}$ & +ve & -ve & + ve \\
\hline at the moment $\mathrm{F}$ in collection & -ve & $+\mathrm{ve}$ & $+\mathrm{ve}$ \\
\hline after inoculation by 8 days. & $+\mathrm{ve}$ & $+\mathrm{ve}$ & +ve \\
\hline Before inoculation by 8 days & $+\mathrm{ve}$ & + ve & $\begin{array}{l}\text { +ve before inoculation } 8 \\
\text { days }\end{array}$ \\
\hline
\end{tabular}




\section{Sampling}

Blood samples were collected at the end of the experiment and harvesting the blood serum and other half were collected in heparinated test tube and used immediately for counting the blood cells using haemocytometer.At the end of the experimental period, animals were fasted overnight sacrificed by cervical dislocation. The mice epididymis was obtained for collection the semen for application the semen analysis.

\section{Semen analysis}

The Canada epididymis of one testis was excised and received in a sterilized Petridis containing warm normal salin of $37{ }^{\circ} \mathrm{C}$, then it was macerated by sterilized scissors to obtained the epididymal content in a suspension that was handled as a semen [20].

1) Sperm abnormalities: It was carried out after the method described [21].

2) Sperm cell concentration per Mel of semen: It was performed according to the method [22].

3) Sperm abnormalities: It was determined using the method [23].

\section{Biochemical analysis}

1) Determination of glutathione reductase (GR) activity according to the method described [24].

2) Determination of reduced glutathione (GSH) according to the method described modified [25].
3) Determination of superoxide dismutase (SOD) activity. According to the method described [26].

4) Determination of glutathione peroxidase activity (GPX) using the biodiagnostic assay [27].

5) Determination of Catalase (CAT) activity [28].

\section{Statistical analysis}

The obtained results were analyzed and graphically represented using the statistical package for social science (SPSS 8.0 software) [29] for obtaining mean and standard error. The data analyzed one -way ANOVA to determine the statistical of difference among groups.

\section{Results and Discussion}

\section{I.Evaluation of anticarcinogenicity of Bleomycin and side effects on EAC \\ Examination of peritoneal fluid for EAC cells using trypan blue stain $0.5 \%$}

Viability test Was done by using trypan blue $0.5 \%$ for staining of ascetic fluid samples and counting of the total, life and dead EAC cells by using hemocytometer and the results were statistically analysed (Table 2). Ascitic fluid samples were stained trypan blue $0.5 \%$, we made ascetic fluid film using glass slides and examined under microscope and it have been noticed that EAC in the fourth group showing numerous life cells not stained blue.

Table 2: Examination viability test revealed total tumor, life and dead cells.

\begin{tabular}{|c|c|c|c|c|}
\hline \multirow[b]{2}{*}{ Groups } & \multirow[t]{2}{*}{ EAC cells } & \multicolumn{3}{|c|}{ Mean \pm SEM (no of cells per $\left.\mathrm{ml} \times 10^{4}\right)$} \\
\hline & & Total tumor cell count & Life cell count & Dead cell count \\
\hline 1 & 1 & $-v e$ & -ve & $-\mathrm{ve}$ \\
\hline 2 & 2 & $74.5 \pm 3.10 \mathrm{a}$ & $73.5 \pm 2.85 \mathrm{a}$ & $1.00 \pm 0.55 \mathrm{a}$ \\
\hline 3 & 3 & -ve & -ve & -ve \\
\hline 4 & 4 & $65.35+2.75 \mathrm{a}$ & $59.65+2.60 \mathrm{a}$ & $5.75+0.60 \mathrm{a}$ \\
\hline 5 & 5 & $62.50 \pm 2.55 \mathrm{a}$ & $58.40 \pm 2.45 \mathrm{a}$ & $4.40 \pm 0.55 \mathrm{a}$ \\
\hline 6 & 5 & $61.5 \pm 2.35 \mathrm{a}$ & $9.75 \pm 0.85 b$ & $51.25 \pm 2.60 \mathrm{a}$ \\
\hline 7 & 7 & $63.10 \pm 2.65 \mathrm{~b}$ & $4.50 \pm 0.25 \mathrm{c}$ & $58.60 \pm 0.60 \mathrm{a}$ \\
\hline 8 & 8 & $10.50 \pm 0.65 \mathrm{c}$ & $3.25 \pm 0.25 \mathrm{c}$ & $7.25 \pm 0.75 \mathrm{c}$ \\
\hline
\end{tabular}

$*$ There is significant difference $(\mathrm{P}<0.05)$

$* *$ There is highly significant difference $(\leq 0.01)$ 
Mean carrying different superscripts are significantly. Oxidative stress was considered to be one of the mechanisms implicated in bleomycin induced treatment [30]. Bleonycin oxygen dependent toxicity occurs via cyclic one electron reduction of the bleomycin molecule, followed by oxidation with molecule and the superoxide radical, an extremely reactive species that produces a variety of toxic radicals and results in several types of damage to biological molecules [31]. In fact, reactive oxygen species (ROS) can attack biomolecules, such as lipid and thiols, in proteins and glutathione, leading to indication of enzymes, cell dysfunction and cell death [32].

Excess generation of ROS and a deficient cellular antioxidant defense system may lead to a state of oxidative stress that can cause oxidative damage to cells by affecting the cell membrane, genetic material, and various enzymatic reactions. ROS levels are normally controlled by intracellular antioxidant defense mechanism, which include the enzymes catalase (CAT) GR, GSH and (Gpx) as well as non-enzymatic antioxidant system [33]. Glutathione peroxidase $(\mathrm{Gpx})$ is a seleno enzyme, two third of which is present in-e- cystol and one-thirds in the mitochondria in the liver. It plays a major role in the reduction of hydrogen peroxide and hydroproxide converted to non-toxic products [34].

The results of the present study revealed depletion in GSH level of Bleomycin in the mice liver and administration of aged garlic after inoculation of EAC cells and replenishes intracellular GSH levels as presented in Table (3). Aged garlic attenuates oxidative stress by increasing the content of hepatic glutathione, leading to the reduction in the level of lipid hydro peroxide. These finding indicate that the increase in free radicals scavenging enzyme followed by a decrease in GSH by bleomycin could be initiated by oxidative stress. The reduction of GSH after bleomycin treatment may have resulted from activity of GPX in reducing hydro peroxides to stable non-radical lipid alcohols utilizing GSH as a source of reducing equivalents. Alternatively, GSH concentration may have been reduced by the direct utilization of GSH as an antioxidant in termination free radical reaction initiated by bleomycin. AGE supplementation, however, provokes a sustained higher level of GSH while nullifying the increasing in the level of antioxidant enzymes.

Table 3: The effects Bleomycin \& AGE on sperm quality in mature mice against EAC cells. (Means \pm SE.)

\begin{tabular}{|c|c|c|c|c|}
\hline $\mathrm{C}_{\text {Groups }}$ & Parameters & $\begin{array}{l}\text { Sperm cell concentration } \\
\qquad 10^{6} / \mathrm{mm}^{3}\end{array}$ & Sperm motility $\%$ & Speram abnormalities $\%$ \\
\hline 1 & & $22.65 \pm 2.35^{\mathrm{c}}$ & $65.15 \pm 1.75^{\mathrm{c}}$ & $19.80 \pm 0.80^{\mathrm{c}}$ \\
\hline 2 & & $16.5 \pm 1.75^{b}$ & $48.55 \pm 1.35^{b}$ & $26.45+1.35^{b}$ \\
\hline 3 & & $25.60 \pm 2.40^{\mathrm{a}}$ & $80.50+3.10^{\mathrm{a}}$ & $14.10 \pm 0.55^{\mathrm{a}}$ \\
\hline 4 & & $14.30 \pm 1.15^{\mathrm{b}}$ & $40.70 \pm 1.80^{b}$ & $36.40 \pm 1.85^{\mathrm{c}}$ \\
\hline 5 & & $18.65+1.80^{b}$ & $52.60+1.45^{\mathrm{c}}$ & $29.15+0.90^{b}$ \\
\hline 6 & & $20.90 \pm 2.15^{\mathrm{c}}$ & $56.60 \pm 1.60^{\mathrm{c}}$ & $21.80 \pm 0.70^{\mathrm{c}}$ \\
\hline 7 & & $23.55+2.60^{\mathrm{c}}$ & $63.40 \pm 1.70^{\mathrm{c}}$ & $20.00+0.95^{\mathrm{c}}$ \\
\hline 8 & & $23.90+2.70^{\mathrm{c}}$ & $67.80+2.10^{\mathrm{c}}$ & $15.70+0.65^{\mathrm{c}}$ \\
\hline
\end{tabular}

Means within the same column have different superscripts are significantly different at $(\mathrm{P} \leq 0.05)$.

Previous study confirmed that the depletion of antioxidants including glutathione and protein bound sulfhydryl groups and the increase in the activity of various anti-oxidant enzymes indicative damage of cell molecules [35]. Under normal physiological conditions, ROS are easily neutralized by antioxidant defense such as glutathione (GSH) and several antioxidant enzymes. However, upon bleomycin treatment, an excess of ROS production can occur and the antioxidant defensed available may be overwhelmed, which may lead to damage in cellular components [36].

Hepatic damage induced by bleomycin treatment in mice, has possibly caused sever 
irritation of oxidant system in these cells [37]. Garlic has been as a medicinal remedy as well as presents disease and enhances vigor. Modern science and medicine have validated many of the traditional uses of garlic and identified its health-promoting compounds. Most of the benefits of garlic are attributed to its high content of organosljur compounds and antioxidant activity, which protect against oxidative damage by reactive oxygen species (ROS) and other beneficial effects (groups $3,4,5,7$, and 8, Table 4). Thus, intake of AGE and the potential increase in glutathione provide additional antioxidant protection in cancer.

Table 4: Mean \pm S.E. of biochemical analysis of antioxidant enzymes activities of the EAC cells inoculated in mature male albino mice and treatment bleomycin and ACE.

\begin{tabular}{|c|c|c|c|c|c|c|}
\hline Groups & Parameters & $\begin{array}{c}\text { Reduced } \\
\text { Glutathione (GSH) } \\
\text { (nmol/mg hepatic } \\
\text { protein) }\end{array}$ & $\begin{array}{c}\text { Glutathione } \\
\text { reductase } \\
\text { ( } \mu \text { mole/gm. hepatic } \\
\text { tissue GR) }\end{array}$ & $\begin{array}{c}\text { Glutathione GRX } \\
\text { peroxidase }(\mathrm{u} / \mathrm{mg} \\
\text { hepatic protein) }\end{array}$ & $\begin{array}{c}\text { Catalase }(\mathrm{CAT}) \\
\text { (u/mg hepatic } \\
\text { protein) }\end{array}$ & $\begin{array}{c}\text { Superoxide } \\
\text { (SOD) dismutase } \\
\text { (u/mg hepatic } \\
\text { protein) }\end{array}$ \\
\hline & 1 & $40.50 \pm 0.40^{b}$ & $23.70 \pm 0.30^{\mathrm{c}}$ & $76.10 \pm 0.50^{\mathrm{c}}$ & $24.30 \pm 0.35^{\mathrm{c}}$ & $19.15 \pm 0.16^{\mathrm{c}}$ \\
\hline & 2 & $22.60 \pm 0.50^{\mathrm{c}}$ & $11.15 \pm 0.70^{\mathrm{a}}$ & $30.90 \pm 1.20^{\mathrm{a}}$ & $19.25 \pm 0.55^{\mathbf{b}}$ & $15.20 \pm 0.25^{\mathbf{b}}$ \\
\hline & 3 & $35.70 \pm 0.75^{b}$ & $26.35 \pm 12.30^{b}$ & $79.25 \pm 0.90^{b}$ & $26.20 \pm 0.70^{\mathrm{a}}$ & $21.40 \pm 0.30^{\mathrm{a}}$ \\
\hline & 4 & $47.10 \pm 1.25^{\mathrm{a}}$ & $21.50 \pm 0.50^{\mathrm{a}}$ & $73.40 \pm 0.35^{\mathrm{a}}$ & $23.60 \pm 0.50^{\mathrm{c}}$ & $20.25 \pm 0.60^{c}$ \\
\hline & 5 & $28.45 \pm 0.60^{\mathrm{c}}$ & $14.30 \pm 0.45^{\mathrm{c}}$ & $49.10 \pm 0.60^{\mathbf{c}}$ & $18.40 \pm 0.60^{b}$ & $16.30 \pm 0.40^{b}$ \\
\hline & 6 & $33.65 \pm 0.70^{\mathrm{c}}$ & $17.60 \pm 0.35^{\mathrm{c}}$ & $56.40 \pm 0.40^{\mathrm{c}}$ & $15.80 \pm 0.75^{\mathbf{b}}$ & $14.25 \pm 0.35^{\mathbf{b}}$ \\
\hline & 7 & $37.15 \pm 0.15^{b}$ & $20.10 \pm 0.55^{\mathrm{c}}$ & $69.80 \pm 1.15^{\mathrm{c}}$ & $21.20 \pm 0.70^{\mathrm{c}}$ & $17.30 \pm 0.40^{\mathrm{c}}$ \\
\hline & 8 & $42.20 \pm 0.30^{\mathrm{a}}$ & $25.20 \pm 0.50^{\mathrm{a}}$ & $79.30 \pm 1.40^{\mathrm{a}}$ & $25.90 \pm 1.30^{\mathrm{c}}$ & $20.30 \pm 0.50^{\mathrm{c}}$ \\
\hline
\end{tabular}

Means within the same column have different superscripts are significantly different at $(\mathrm{P} \leq 0.05)$.

The results showed that in the all treated groups the number of adenomas increased contmuous over the year, but in the aged garlic group, AGE suppresses the progression of pre. concerous colon lesions and thus would prevent them from developing into full blown colon cancer [38]. AGE and bleomycin, with

Figure 1: Negative control, mature male mice spermatozoon. $($ Bar $=100 \mu \mathrm{m})$.

Aged Garlic Extract could protect cells which line the veins and arteries from damage caused by free radicals by enhancing the activity of antioxidant enzymes (the glutathione (GSH) redox cycle). SOD is their high antioxidant activity, which would help prevention of pathological complications in diabetes. The potential therapeutic role of AGE in diabetes is now being tested in clinical trial involving patient with type 2 diabetes [39].

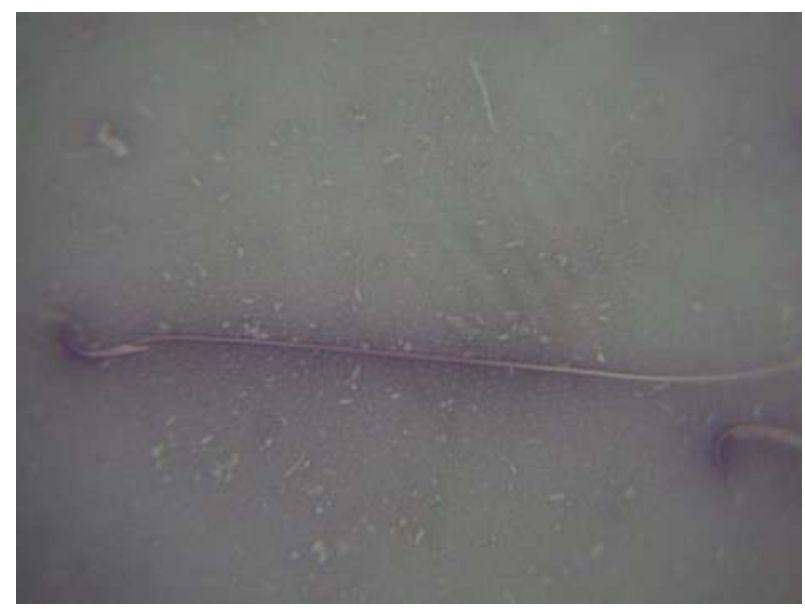

another potent intra cellular antioxidant. AGE was found to time - and dose - dependently enhance intra cellular GSH level, glutathione disulfide reductase and SOD and thus may help to protect the cardio vascular system [40]. Bleomycin exerts its antitumor effect by 
inducing tumor cell death, while inhibition of tumor angiogenesis may also be important. The cytotoxicity occurs by induction of free
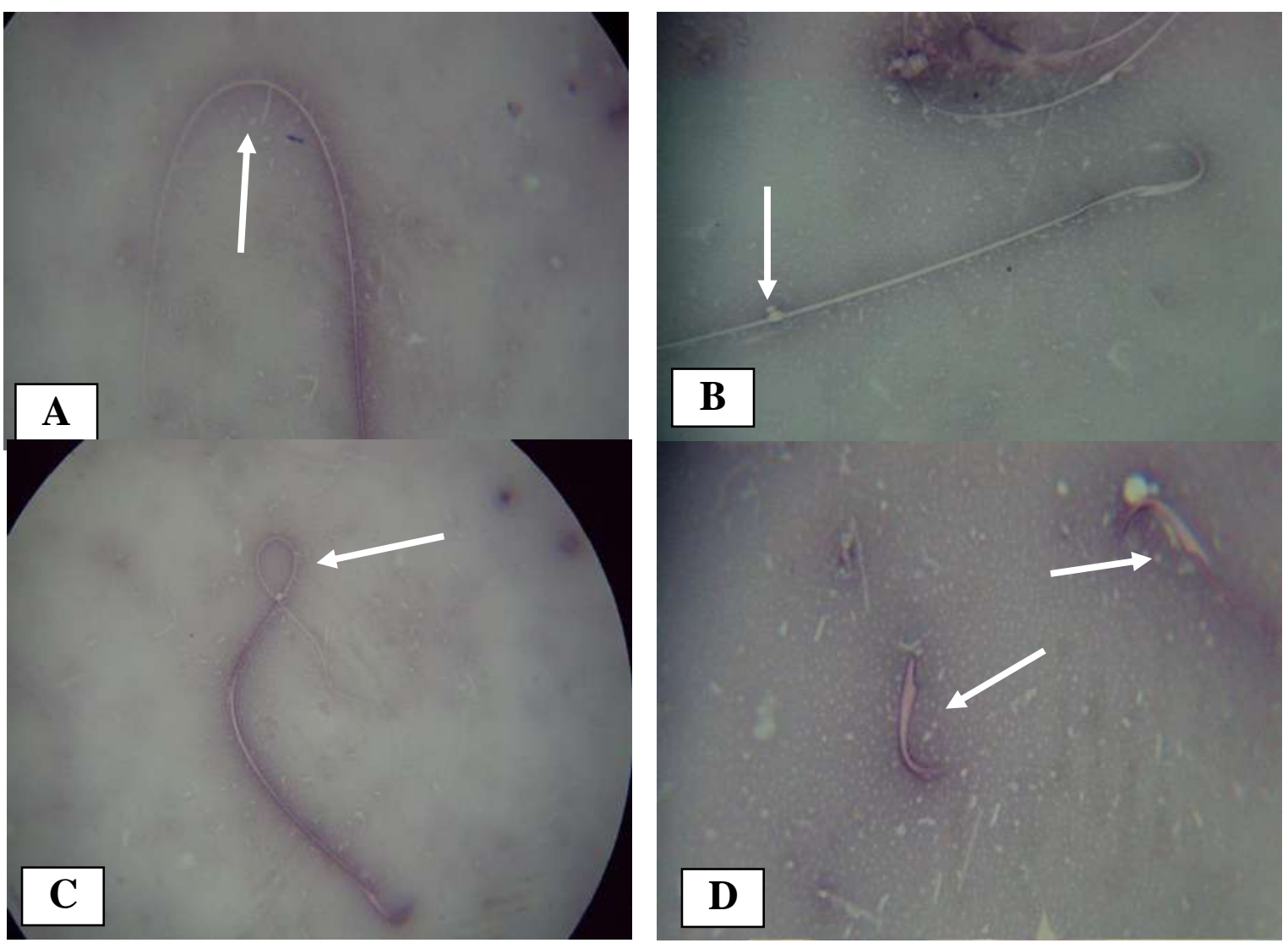

radicals. Bleomycin forms a complex with $\mathrm{Fe}^{+++}$, resulting in reduction of oxygen to free radicals.

Figure 2: Mature male mice spermatozoon of groups inoculated with EAC cell and treated by Bleomycin and AGE showing the following. A. Abnormal tail shape, B. protoplasmic droplet. C. Curved Tail, D. Detached head and Tail. $($ Bar $=100 \mu \mathrm{m})$.

\section{Conflict of interest}

The authors declare that they have no conflict of interest.

\section{References}

[1] Tan G., Gyllenhaal C., Soejarto D.D. (2006): Biodiversity as a source of anticancer drugs. Curr. Drug Targets 7:265277.

[2] Bryant R. (2003): Managing side Effects of Childhood Cancer Treatment Children's Neuroblastoma Cancer Foundation. Journal of Pediatric Nursing 18:118-125.

[3] Julia D.M. and Lara B.M. (2010): The Abramson cancer center of the University of pennsyvania a special note to the reader : all the chemotherapy drugs discussed herein can be found on Oncolink Rx. 
[8]Reuda D., Marquez J. and Guma M. (2004): Treatment of stage I and II Hodgkin's lymphoma with ABVD chemotherapy: results after 7 years prospective study. Annals of Oncology, 15:1789-1804.

[9] Hay, J., Sharhzeidi, S., Laurent, G. (1991): Mechanisms of bleomycin -induced lung damage. Arch. Toxicol., 65, 81-94.

[10] Cortijo J., Cerda-Nicolas M., Serrano A., Bioque G., Estrela J.M., Santangelo F., Esteras A., Llombartbosch A. and Morcillo E.J. (2001): Attenuation by oral Nacetylcysteine of bleomycin -induced lung injury in rats. Eur. Respir. J., 17: 1228-1235.

[11] Burger R.M., Peisage, J. and Horwitc S.B. (1981): Activated bleomycin : a transient complex of drug, iron and oxygen that degradates DNA. J. Biol. Chem., 256:11636-11644.

[12] Crook S.T., Comis R.L. and Einhorn L.H. (1977): Effects of variations in renal function on the clinical pharmacology of bleomycin administrated as i.v. bolus. Cancer treat Rep., 61:1631-1636.

[13] Ikezaki S., Nishikawa T., Enami F., Furukawa T., Imazawa C., Uneyama S., Fukushima M. and Takahashi A. (1996): Inhibitory effects of the dietary antioxidants butylated hydroxyanisole and butylated hydroxytoluene on bronchioalveolar cell proliferation during the bleomycin -induced pulmonary browsing process in hamsters. Food Chem. Toxicol., 34:327-335.

[14] Molina, M., Serrano, M., Bulbena, O., Closa, D. (2006): Losatan attenuates bleomycin induced lung fibrosis by increasing prostaglandin $\mathrm{E}_{2}$ synthesis. Thorax, 61:604-610.

[15] Kim J.Y., Lee K.H., Lee B.K., Roi J.Y. (2005): Peroxynitrite modulates release of inflammatory mediators from guinea pig lung mast cells activated by antigen antibody reaction. Int. Arch Allergy Imjmunol., 137:104-114.

[16] Povirk L.F. and Austin M.J. (1991): Genotoxicity of bleomycin. Mutat Res. 257:127-143.
[17] Povirk L.F. and Houlgrave C.W. (1989): Effect of apurinic / apyrimidinic endonucleases and polyamines on DNA treated with bleomycin and neocarzinostatin: specific formation and cleavage of closely opposed lesions in complementary strands. Biochemistry, 27:3850-3857.

[18] Mir, L.M., Tounekti O., Orlowski, S. (1996): Bleomycin: revival of an old drug. Gen Pharmacol., 27:745-748.

[19] Kasuga S., Uda N., Kyo K., (2000): Pharmacological activites of aged garlic extract in comparison with other preparation. J. Nuttr. (131) : 1080s 1084 s.

[20] Hafez, W. H. (1970): Reproduction and breeding techniques for laboratory animals. Lea and Fabiger eds, philadephia, pp: 310-321.

[21] Slott, V., Suarez, J. and Perreault, S. (1991) : sperm motility analysis : methodologiyc considerations. Reproductive Toxicology, 5:449-458.

[22] Robb, G., Amann, R. and Killian. G. (1978) : Daily sperm production and epididymal reserves of pubertal and adult rats. J. Reprod. 8c fertility, 54:103-107.

[23] Filler, R. (1993): Methods for evaluation of rat epididymal sperm morphology. Cited in Methods in Toxicology, Academic press Limited, London. UK. Pp. 334-343.

[24] Beutler E. (1975) : Glutathione instability of drug. Sensitive red cells ; a new method for the in vitro detection of drug sensitivity. J. Lab. Clini Med., 49:84-95.

[25] Beutler E., Duron. O., and Kelly B. M. (1963) : Improved method for the determination of blood glutathione. J. Lab. Clin. Med., 61:822-888.

[26] Sies H. (1991): Oxidative stress: introduction. In oxidative Stress: Oxidants and Antioxidants, ed. sies, $\mathrm{H}$. pp.xv-xxii. Academic Press. London.

[27] Paglia D. E. and valentine W. N. (1967): Studies on the quantative and qualitative characterization of erythrocyte 
glutathione peroxidase. J. Lab. Clin. Med. 70:158-169.

[28] Sinha A-K., (1972): Colorimetric assay of catalase. Analyticax Biochemistry, 47, 389-394.

[29] SPSS, (1997): Statistical package for social sciences. 8.0 for windows, USA copyright, Spss Inc.

[30] Turkez, H., Aydin, E. and Aslan A., (2012): oxidative stress of bleomycin in human lymphocytes. Cytotechnology; 64 (6): $679-86$.

[31] Yusupova, S., Malikova, S. and turner, N. (2017): NADPH cytochrome-p-450 reductase of Bleomycin anticancer agents to free radicals. Notl. Acad. Sci. 94:123-129.

[32] Biase, R., Naidu, S. and Rao, N. (2016): Oxidative stress and oxidative damage in chemical carcinogenesis. Toxicol. (55):396-402.

[33] Madyasthe, R. (2016): Antioxidant defense against reactive oxygen species causing genetic and other damage. Mutation, 1012:813-819.

[34] Patel, S., Lipman, R. and Xan, M. (2017): Antioxidant effects of phytosomes in carbon tetrachloride-induced liver damage in mice. Hepatic J. (115):930937.
[35] Ahmed M. and Siddiqui M.K.J. (2007): Low level lead exposure and oxidative stress: current opinions. Clin. Chim. Acta, 383:57-64.

[36] Baetzold. R. (2016): Antioxidant defense mechanisms. Free, Rad. Res. 119:931938.

[37] Naghsh, N., Noori, A., Aqababa, H. and Dehkardi S. (2012): Effect of NPs on ALT activity and white blood cells level in male wistar rats, in vivo condition. Zahedan J. Res. Med. Sci. 14(7):34-37.

[38] Tanaka S., Harum K., Yoshthara, M., Kajlyama. G., Kira, K., Amagase, H. and Chayama, K. (2006): Aged garlic extract has potential suppresse level effect on colorectal adenomas in luimaiis. J Nutra., 136:8215-8265.

[39] Ahmed M. S. and Ahmad N., (2006): Antiglycation properties of aged garlic extract: possible role in prevention of diabetic complications. J. Nutr 136:79657995.

[40] Geng, Z. and Lau, B. (1997): Aged garlic extract (AGE)- part I: the different forms of garlic and why AGE is a better health choice. Let's talk nutrition phytother. Res. 11:54-56. 


\section{الملخص العربى}

\section{دراسات فارماكولوجية على عقار البليوميسين كعلاج للسرطان والعلاج الوقائى بالثوم المعتق}

' صبرى عبد المتعال، ' محمد حسن خبرى ، ' أحمد عبده سعيد ، 'مجدى فكرى ابو الفتوح و 'شيماء أحمد عبد العزيز

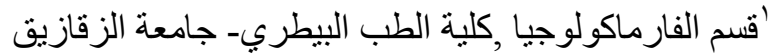

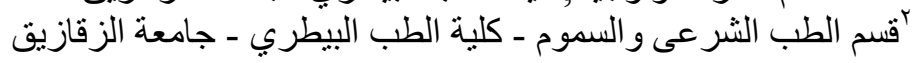

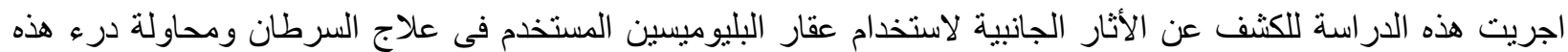

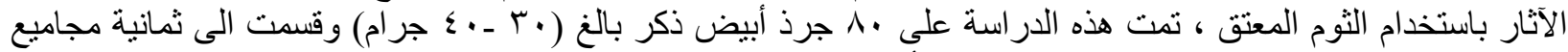

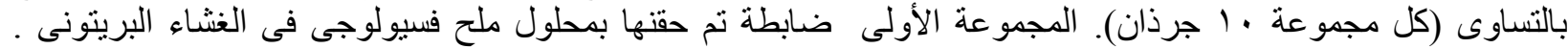

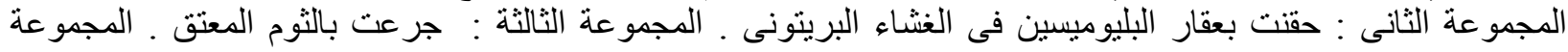

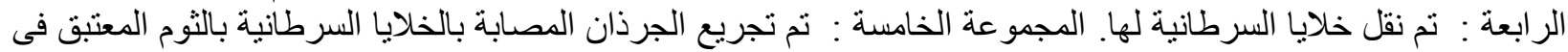

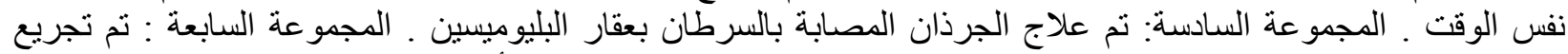

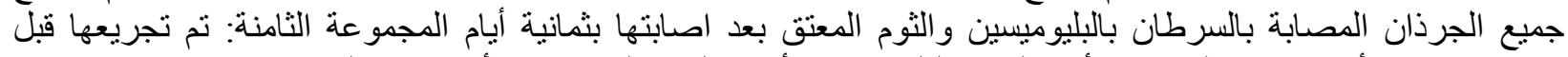

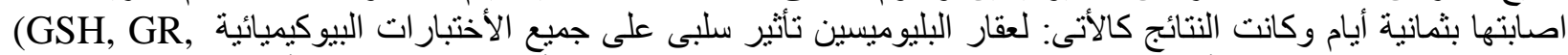

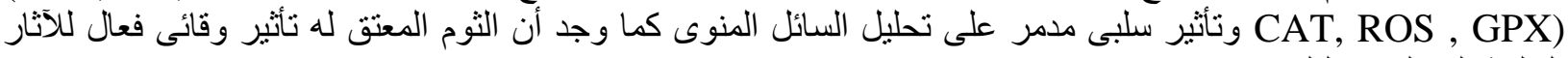
السلبية التى لعقار البليوميسين. 